\title{
COVID-19 Pandemic and Government Policies to Control its Situation in Pakistan
}

\section{Raja Waqar Ali ${ }^{1,2}$, Muhammad Adnan Akram ${ }^{3 *}$, Mobeen Haider ${ }^{4}$, Imran Nazir $^{5}$, Abdul Manan ${ }^{3}$ and Muhammad Faisal ${ }^{6}$}

${ }^{1}$ Lanzhou University Second Hospital, Lanzhou, Gansu Province, China

${ }^{2}$ Lanzhou University Second School of Clinical Medicine, Lanzhou, Gansu Province, China

${ }^{3}$ School of Life Science, Lanzhou University, Lanzhou, Gansu Province, China

${ }^{4}$ Doctors Institute of Medical Sciences, Lahore, Pakistan

${ }^{5}$ Aziz Bhatti Shaheed Teaching Hospital Gujrat, Punjab Province, Pakistan

${ }^{6}$ M-III Allied Hospital Faisalabad, Punjab Province, Pakistan

*Corresponding Author: Muhammad Adnan Akram, School of Life Science, Lanzhou

University, Lanzhou, Gansu Province, China.
Received: May 19, 2020

Published: May 29, 2020

(C) All rights are reserved by Muhammad

Adnan Akram., et al.

\begin{abstract}
Objective: The current study is aimed to provide ongoing situation of COVID-19 pandemic timeline in Pakistan compared with its border sharing countries (BSC) and the strategies adopted by government to combat the newly emerged COVID-19 that was first detected in Wuhan city of China in December 2019.

Methods: Our study is desktop based and we collected data from the official government's web sources, already published papers and by other means of electronic and printing media.

Results: Pakistan has reported total 38,799 cases of COVID-19 and 834 deaths (2.15\%) till 15th May, 2020; which reflects the lower number of cases and deaths as compared to its border sharing countries (BSC) except Afghanistan. Sindh province $(\mathrm{n}=14,916)$ and Karachi district $(n=10,500)$ has highest number of confirmed cases and only one death has reported in Azad Jammu Kashmir (AJK) region.

Conclusion: We concluded that the strategies and preventive measures taken by Pakistan against COVID-19 remain satisfactory but not exceptional, despite having its limited resources and fragile economy comparing to its border sharing countries (BSC). Nevertheless, government should continue to improve its strategies to combat this pandemic as well as the world and need to find vaccine against COVID-19.
\end{abstract}

Keywords: Corona Pandemic; Epicenter; Lockdown; Preventive Measures

\section{Abbreviations}

AJK: Azad Jammu Kashmir; BSC: Border Sharing Countries; COVID-19: Corona Virus Disease 2019; GB: Gilgit Baltistan; ICT: Islamabad; MERS: Middle East Respiratory Syndrome; SARS: Severe
Acute Respiratory Syndrome; UK: United Kingdoms; USA: United States of America; WHO: World Health Organization

\section{Introduction}

The first epidemic of corona virus related septicity was reported in 2002-2003, which affected 29 countries in 4 continents i.e. Eu- 
rope, Asia, North and South America. It accounted for more than 8000 cases that were identified with $9.5 \%$ of mortalities [1]. Previous studies showed that corona viruses have been found in both humans and animals. While it was disastrous, but to the date there is no proper vaccine available against such diseases. Consequently, adequate preventative measures were suggested against the pandemic of corona virus, such as, monitoring and surveillances change in eating habits etc. $[2,3]$. However, Pakistani experts conducted a detailed study about infectious diseases especially caused by viruses such as Polio, Dengue, and Hepatitis. Meanwhile, it was advocated that Pakistan is also facing several problems including natural disasters, such as flood, earth quake and epidemic of various microbial diseases. Thus, Pakistan government is required to go for all-inclusive health policy of preventative measures in overall health care settings [4].

Presently, the whole world has experienced a fresh persuasive challenge in the shape of Corona virus disease-2019 simple called COVID-19 [5]. While medical scientists are familiar to Corona viruses, the outbreak of this novel $5^{\text {th }}$ type of Corona virus called SARS - COV2 has its unique features and developing epidemiology. Corona viruses belongs to large family, which causes different diseases like common cold, Severe Acute Respiratory Syndrome (SARS-CoV), Middle East Respiratory Syndrome (MERS-CoV) etc [3]. The present strain [6] is a new for scientists, medical experts and researchers and has not been identified and reported in the past, especially in humans [5].

COVID-19 have been spread out in more than 210 countries including Pakistan since the first case was identified in Wuhan City of China in December 2019 [7] and declared a world pandemic by WHO on $11^{\text {th }}$ March 2020 [8]. In order to formulate epidemic and pandemic precautionary measure quarantine is thought as one of the effective ancient preventatives and has a crucial role in it, which is simply the isolation of suspected person for a specific time period $[9,10]$. While in isolation, if a person develops signs and symptoms of a particular disease, he or she is transmitted to hospital for further evaluation and treatment. If s/he doesn't establish any symptoms, s/he is set free [11]. Quarantine time period varies for disease to disease. Incubation or window period for corona virus is estimated from 1 - 14 days or even longer for depending on individuals as quarantine period for corona virus to establish its specific sign and symptoms $[12,13]$.
Pakistan is sharing its border with India, Afghanistan, Iran and China, to the east, northwest, and west and in the northeast, respectively [14]. Pakistan and China has very good terms with increasing rate of travel as well as trade over the last few years. The travelers can be a strong cause of spreading or transmission of COVID-19 in Pakistan, which is vulnerable. Pakistan has good relations with Iran, and communities of both countries had religious attachments. Every year 0.7 million Pakistani Muslims visits Iran for pilgrimage/Zyaraat purpose (to visit Holy Places and Shrines in Iran) and mostly people from Pakistan, Yemen, Bahrain, Qatar, Afghanistan and other countries visit in the early Spring season for this purpose. India and Afghanistan has not as much good diplomatic relationship with Pakistan, so that's why the less chances of COVID-19 transmission through these countries [1].

These factors can increase COVID-19 importation risk to Pakistan. It demands effective preparations and strict measures for the early detection of COVID-19 cases and strong measures to control further spread of this pandemic. Therefore, in response to this situation government has developed a national strategic action plan to fight and control COVID-19 pandemic situation in the country [6].

\section{Aim of the Study}

The aim of this study is to provide current data about COVID-19 in Pakistan and its border sharing countries (BSC). Moreover, to provide framework for all stakeholders and policy makers to make effective policies and strategies to detect, prevent and respond to COVID-19 situation. Furthermore, to compare Pakistan's current situation with BSC (China, Iran, Afghanistan and India) and with most affected top five countries of World (USA, Spain, Italy, UK and France).

\section{Methods and Approaches}

The present study was a desk-top study to inform up-to-date facts and figures for COVID-19 outbreak situations in Pakistan and strategies adopted by the local government to overcome its pandemic burdens. We collected the data and information about COVID-19 from published papers/data, government official websites, printing and electronic media till $15^{\text {th }}$ May 2020. All the collected data was analyzed by using SPSS 21.0 software.

\section{Results and Discussions \\ COVID-19 current situation in Pakistan}

Pakistan detected first two positive cases of COVID-19 in Karachi city of Sindh province on $26^{\text {th }}$ February 2020 and it was re- 
ported that they had came back from Iran after pilgrimage/Zyaraat [15]. First source of COVID-19 transmission in Pakistan was the returning of Pakistanis from foreign countries i.e. Iran, Saudi Arabia, Spain, Italy and UK etc. where they went for Pilgrimage/Ummrah/ Zyaraat/Tableegh purpose or for the sake of job/employment. Second main source of epidemic was local transmission (more than $75 \%$ ) of virus through social contacts of above mentioned imported unconscious positive patients who had traveled to affected countries. Nevertheless no any single case was reported being imported from China to Pakistan because of the consensus and extra precautionary preventive measures taken by both governments (Pakistan and China) about exit/entry of COVID-19 infected persons in the both countries [16-18].

According to our study the total number of 38,799 confirmed cases of COVID-19 has reported in Pakistan till 15 ${ }^{\text {th }}$ May, 2020; which is almost one half of the expected cases by government. In Pakistan total deaths due to COVID-19 account for $2.15 \%$ ( $\mathrm{n}=$ $834)$, total recoveries $28.05 \%(n=10,880)$ and active cases reported $69.81 \%(n=27,085)$ so far (Table $1 \mathrm{a})$. Health authorities have conducted 3,59,264 diagnostic tests in the suspected individuals till $15^{\text {th }}$ May, 2020 [16-18].

\section{Provincial/regional distribution of cases across country}

The most affected province in Pakistan is Sindh province, where total confirmed cases of COVID-19 are $(n=14,916)$ followed by Punjab ( $n=14,201)$, Khyber Pakhtunkhwa (KPK) $(n=5,678)$, Balochistan ( $n=2,457)$, Islamabad (ICT) ( $n=921)$, Gilgit Baltistan (GB) ( $n=518)$ and Azad Jammu Kashmir (AJK) ( $n=108)$, respectively (Figure 1 and table 1a) [18]. The deaths ratio in KPK and Sindh remains relatively higher than Punjab that is $34.89 \%, 30.57 \%$ and $29.37 \%$, respectively. Whereas, the death ratios in the Balochistan, ICT and GB regions account for 3.7\%, $0.84 \%$ and $0.48 \%$, respectively; and only one death has been reported in AJK with $0.11 \%$ so far. Active number of cases remains higher in Sindh province which accounts for $38.44 \%$ and lowest ratio recorded for GB and AJK region that accounts for $1.33 \%$ and $0.28 \%$, respectively. While the ratio of active cases remains slightly higher in Sindh (38.44\%) and Punjab (36.60\%) than KPK (14.63\%), Balochistan (6.33\%), ICT $(2.37 \%)$ and GB (1.33\%) [16-18]. Whereas, minimum active cases has been reported in $\mathrm{AJK}(0.28 \%)$. In measures of total recoveries AJK was ranked top with $70.37 \%$ and lowest ratio was observed for ICT with $10.86 \%$ (Figure 2 and table $1 \mathrm{a}$ ).
Top five highly targeted districts/areas by COVID-19 in Pakistan

Since the COVID-19 pandemic in the country, the Karachi district (Capital city of Sindh province) has been vigorously contaminated with COVID-19 with total cases of 10,500 (27.06\%), out of 38,799 positive cases nationwide, followed by Lahore where 6,298 (16.23\%) cases has been reported as second most affected district so far. District Peshawar reported 2,087 (5.38\%) cases, Multan confirmed 896 (2.30\%) cases and Rawalpindi 763 (1.96\%) positive cases of COVID-19 and Rawalpindi ranked $5^{\text {th }}$ among top five affected districts in Pakistan by COVID-19 (Table 1b) [16-18].

Pakistan's current scenario of COVID-19 pandemic compared with its border sharing countries (BSC)

Pakistan shares its borders with India, Afghanistan, Iran and China, to the east, northwest and west and in the northeast, respectively [14]. Unluckily, Pakistan geographically lies between two key epicenter and major source for the COVID-19 pandemic in the region that are Iran and China [19]. Therefore, the risk of importation/transmission of COVID-19 through these neighbors was not neglect able. In our study, we determined that total cases of these two countries (Iran and China) account for $60.42 \%$ ( $n=1$, 99,576) with compared to Pakistan and its BSC; whereas other two neighbors India and Afghanistan accounted for only $27.84 \%$ ( $\mathrm{n}=$ 91,993). While Pakistan ranked $4^{\text {th }}$ among its BSC i.e. $11.74 \%(\mathrm{n}=$ $38,799)$. Total number deaths in four neighboring countries including Pakistan accounted for 15,275 while ratio of deaths in Iran was the highest with $45.18 \%(n=6,902)$, China $30.33 \%(n=4633)$, India 18.02\% ( $n=2,753)$, Pakistan 5.46\% $(n=834)$ and Afghanistan the lowest $1.01 \%(n=153)$ (Figure 2 and table $2 a)[20,21]$.

\section{Pakistan position in the top five most affected countries}

The globally confirmed COVID-19 cases have reported by World Health Organization (WHO) reached 4,628,785 totally so far (till $15^{\text {th }}$ May 2020) [21]. Pakistan is the world's fifth-most populous country in terms of human population exceeding over 212 million therefore any world pandemic risks are at high to be imported in the country. Although many overseas Pakistanis are living and working across especially in Europe, Asia, Middle East and America. According to the WHO COVID-19 World situation report 101 $[20,21]$ and other official web sources, we noted that USA, Spain, Italy, UK and Russia are the most affected top five countries in the 


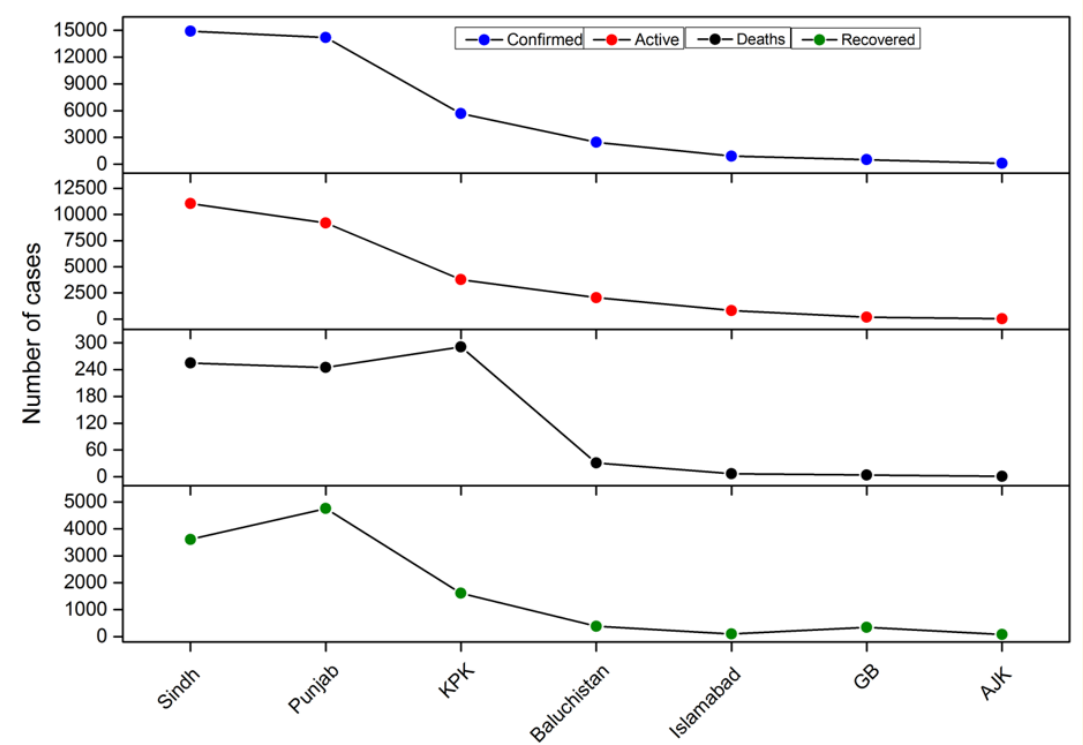

Figure 1: Provincial/regional distribution of COVID-19 cases in Pakistan.

\begin{tabular}{|l|l|l|l|l|}
\hline $\begin{array}{c}\text { Region/ } \\
\text { Province }\end{array}$ & Confirmed & Active & Recovered & Deaths \\
\hline Pakistan & 38,799 & 27,085 & 10,880 & 834 \\
\hline Sindh & 14,916 & 11,055 & 3,606 & 255 \\
\hline Punjab & 14,201 & 9,199 & 4,757 & 245 \\
\hline KPK & 5,678 & 3,774 & 1,613 & 291 \\
\hline Balochistan & 2,457 & 2,043 & 383 & 31 \\
\hline Islamabad & 921 & 814 & 100 & 7 \\
\hline GB & 518 & 169 & 345 & 4 \\
\hline AJK & 108 & 31 & 76 & 1 \\
\hline
\end{tabular}

(a) Number of COVID-19 cases in Pakistan and its different Provinces/regions.

PK: Khyber Pakhtunkhwa; GB: Gilgit Baltistan; AJK:

Azad Jammu Kashmir.

\begin{tabular}{|l|c|c|c|}
\hline District/Area & Province & Cases \% age & Total cases \\
\hline Karachi & Sindh & $27.06 \%$ & 10,500 \\
\hline Lahore & Punjab & $16.23 \%$ & 6,298 \\
\hline Peshawar & KPK & $5.38 \%$ & 2,087 \\
\hline Multan & Punjab & $2.31 \%$ & 896 \\
\hline Rawalpindi & Punjab & $1.96 \%$ & 763 \\
\hline
\end{tabular}

(b) Number of COVID-19 cases in top five affected districts/areas of Pakistan.

Table 1: COVID-19 overall situation in Pakistan.
World till $15^{\text {th }}$ May, $2020[20,21]$. The highest number of cases was reported in USA ( $\mathrm{n}=1,484,285)$ and lowest in the Italy ( $\mathrm{n}$ $=2,23,885)$. The demographic situation of COVID-19 cases incidence is notably lower in Pakistan that is $0.84 \%(n=38,799)$ as compared with worldwide reported cases (Figure 3 and table $2 \mathrm{~b}$ ).

Overall, in the World mortality rate of COVID-19 is $6.67 \%$ and it's varying from one to another country. Pakistan's reported cases rate is $0.84 \%$ and mortality rate is $0.27 \%$ as compared to world [17].

Government strategies/policies against COVID-19 and reliefs for Pakistani citizens

The first case of corona pandemic was identified in Wuhan City of China in December 2019 [7] and declared a world pandemic by WHO on $11^{\text {th }}$ March 2020 [8]. The Pakistan government delivers the COVID-19 easing strategies with their measures, especially after said declaration. Main steps were taken as:

- Government started from partial/smart lockdown (particularly in the epidemic areas) and closure of all major public and private sectors including education and other government offices [18]. 


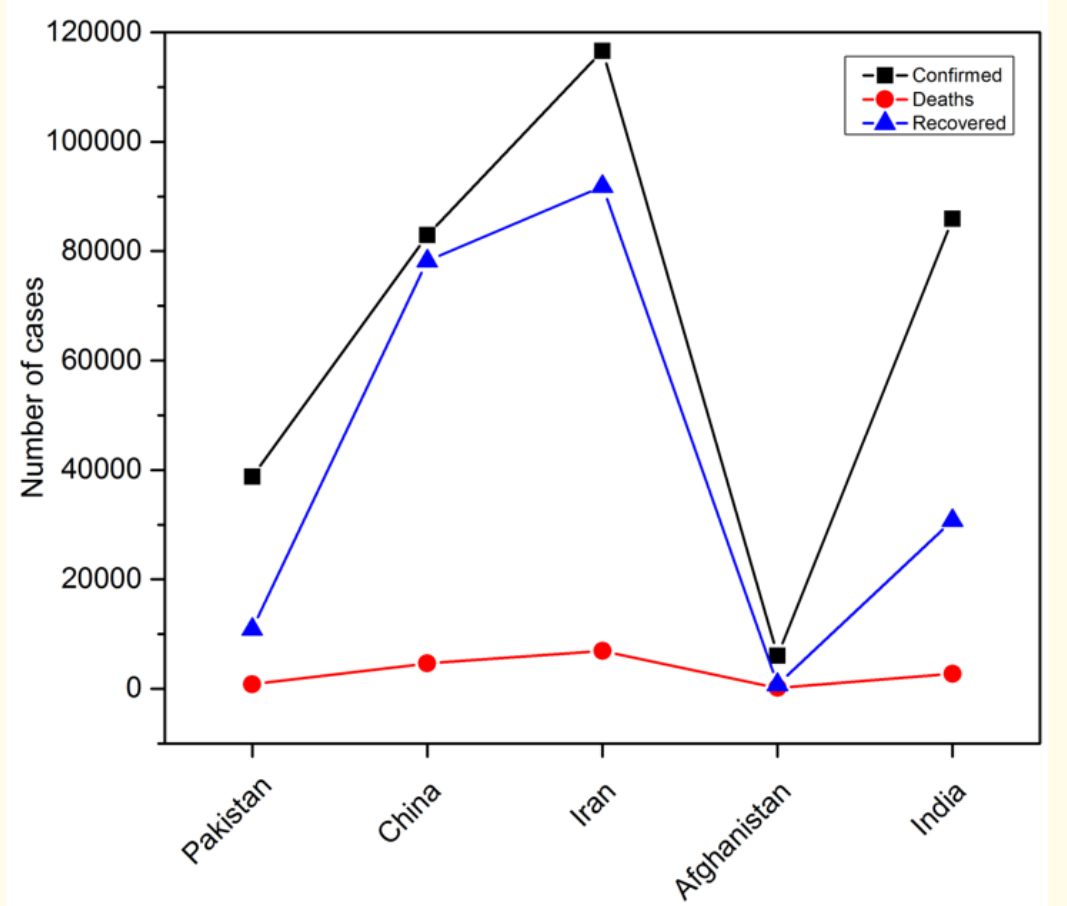

Figure 2: Current scenarios of COVID-19 in Pakistan and its border sharing countries (BSC).

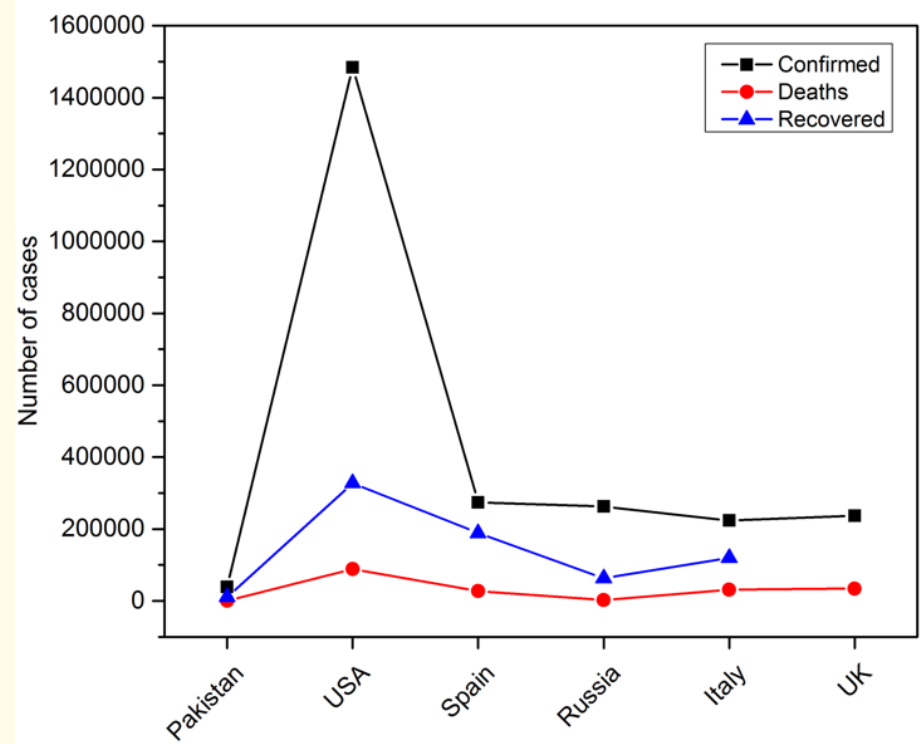

Figure 3: Comparison of COVID-19 situations in Pakistan with top five countries affected by COVID-19 in the World. 


\begin{tabular}{|l|l|l|l|}
\hline \multicolumn{1}{|c|}{ Country } & Confirmed & Deaths & Recovered \\
\hline Pakistan & 38,799 & 834 & 10,880 \\
\hline China & 82,941 & 4,633 & 78,219 \\
\hline Iran & $1,16,635$ & 6,902 & 91,836 \\
\hline Afghanistan & 6,053 & 153 & 745 \\
\hline India & 85,940 & 2,753 & 30,773 \\
\hline
\end{tabular}

(a) Comparison of COVID-19 cases between Pakistan and its border sharing countries (BSC).

\begin{tabular}{|l|c|c|c|}
\hline Country & Confirmed & Deaths & Recovered \\
\hline Pakistan & 38,799 & 834 & 10,880 \\
\hline USA & $1,484,285$ & 88,507 & $3,27,751$ \\
\hline Spain & $2,74,367$ & 27,459 & $1,88,967$ \\
\hline Russia & $2,62,843$ & 2,418 & 63,166 \\
\hline Italy & $2,23,885$ & 31,610 & $1,20,205$ \\
\hline UK & $2,36,711$ & 33,998 & NA \\
\hline
\end{tabular}

(b) Comparison of COVID-19 cases between Pakistan and in the top five most affected countries of the World.

Table 2: Comparison between number of COVID-19 cases in Pakistan and other counties.

- $\quad$ "Sehat Tahaffuz" helpline 1166 was launched on $6^{\text {th }}$ February, 2020 to provide health-related information and services to the people, especially for COVID-19 [22].

- $\quad$ Closed all borders inside the country and also closed trade with all border sharing countries (BSC) for time being because of COVID-19 and suspend all the flights operations domestically and international [23].

- $\quad$ Early case detection, tracing and trailing of contacts, communication risks and social distancing to control the COVID-19 situation in the country. Government has setup various quarantine centers $(n=139)$, isolation centers $(n=215)$ and testing centers $(n=16414)$ against corona virus outbreak; in addition designated tertiary care and field hospitals $(n=35)$ were also established across whole country in response to overcome health burdens $[15,18]$.

- $\quad$ Prime Minister's COVID-19 Relief Fund-2020 has been setup to compete this pandemic and to support affecters [24]; and also launched volunteers Corona Relief Tiger Force aiming to assist government for the food distribution to the needy people and spread public awareness about present corona epidemic [22,25].

- $\quad$ Ehsaas program has been announced for the vulnerable persons by current corona virus [22].

\section{Conclusion}

Pakistan is a developing country and it's a big challenge for such country to fight against COVID-19 with limited resources and unstable economy. Our results showed that the strategies adopted and preventive measures taken by Pakistan against COVID-19 remain satisfactory until now but not outstanding; and government needs to further emphasize and improve strategies to combat this pandemic. Here, the present position of Pakistan for COVID-19 is not bad as compared to the border sharing countries (BSC) and other highly affected countries by present corona epidemic. It's all due to strong policies and on time actions taken by government to combat COVID-19 situation in the country. No doubt, Pakistan's economy, resources, social and religious nature; and political infrastructure are great challenge for the government as well as for the nation to cope COVID-19 pandemic. While, WHO has warned COVID-19 as a very high risk and health assault for whole globe. It is the need of time to find or discover novel effective vaccine to treat COVID-19, improve health strategies and effective precautionary measures to deal with present corona strain COVID-19. In future we can focus on the use of already available drugs for the treatment of COVID-19 and work on its vaccination.

\section{Author's Contribution}

MAA and RWA collected data and written manuscript. MH and IN compiled and analyzed data; whereas AM and MF edited manuscript.

\section{Conflict of Interest}

All the authors declared that there are no known conflicts of interest associated with this publication.

\section{Bibliography}

1. Badshah SL., et al. "Spread of Novel Coronavirus by Returning Pilgrims from Iran to Pakistan". Journal of Travel Medicine (2020).

2. Graham RL., et al. "A decade after SARS: strategies for controlling emerging coronaviruses". Nature Reviews Microbiology 11.12 (2013): 836-848. 
3. Lai CC., et al. "Severe acute respiratory syndrome coronavirus 2 (SARS-CoV-2) and corona virus disease-2019 (COVID-19): the epidemic and the challenges". International Journal of Antimicrobial Agents (2020): 105924.

4. Khalil AT., et al. "Emerging viral infections in Pakistan: issues, concerns, and future prospects". Health Security 15.3 (2017): 268-281.

5. Lippi G and M Plebani. "The novel coronavirus (2019-nCoV) outbreak: think the unthinkable and be prepared to face the challenge". Diagnosis (2020): 1.

6. National action plan for preparedness and response to Corona virus disease (COVID-19) Pakistan (2020).

7. Bogoch II., et al. "Pneumonia of Unknown Etiology in Wuhan, China: Potential for International Spread Via Commercial Air Travel". Journal of Travel Medicine (2020).

8. Qasim M., et al. "Data model to predict prevalence of COVID-19 in Pakistan". Med Rxiv (2020).

9. Tognotti E. "Lessons from the history of quarantine, from plague to influenza A". Emerging Infectious Diseases 19.2 (2013): 254

10. Hou C., et al. "The effectiveness of the quarantine of Wuhan city against the Corona Virus Disease 2019 (COVID-19): well-mixed SEIR model analysis". Journal of Medical Virology (2020).

11. Benjamin GC., et al. "Quarantine stations at ports of entry: protecting the public's health”. National Academies Press (2006).

12. Fielding C., et al. "Disease associated with equine coronavirus infection and high case fatality rate". Journal of Veterinary Internal Medicine 29.1 (2015): 307-310.

13. Backer JA., et al. The incubation period of 2019-nCoV infections among travellers from Wuhan, China (2020).

14. Kiran H., et al. "Understanding mountain poverty in the hindu kush-himalayas: Regional report for Afghanistan, Bangladesh, Bhutan, China, India, Myanmar, Nepal, and Pakistan". International Centre for Integrated Mountain Development (ICIMOD) (2011).

15. Waris A., et al. "COVID-19 outbreak: current scenario of Pakistan". New Microbes and New Infections (2020): 100681.
16. Government of Islamic Republic of Pakistan. National Command and Operation Center (2020).

17. National Institute of Health Islamabad. COVID-19 live dashboard (Pakistan) (2020).

18. The Ministry of National Health Services, P. Regulation and coordination (2020).

19. Saqlain M., et al. "Is Pakistan prepared to tackle the coronavirus epidemic?" Drugs and Therapy Perspectives (2020): 1-2.

20. World Health Origination. Situation report - 101. (2020).

21. World Health Organization. Coronavirus (2020).

22. National Command and Operation Center, G.o.I.R.o.P. (2020).

23. Pakistan International Airlines (PIA), G.o.P. Travel updates and information (2020).

24. Ministry of Foreign Affairs, G.o.P. PRIME MINISTER'S RELIEF FUND FOR COVID-19. (2020).

25. Government of Islamic Republic of Pakistan. Prime Minister Covid-19 Relief Tigers Force (2020).

\section{Assets from publication with us}

- Prompt Acknowledgement after receiving the article

- Thorough Double blinded peer review

- Rapid Publication

- Issue of Publication Certificate

- High visibility of your Published work

Website: www.actascientific.com

Submit Article: www.actascientific.com/submission.php Email us: editor@actascientific.com

Contact us: +919182824667 